\title{
Analysis of present day spread of classical swine fever in the world
}

Nychyk S. ${ }^{1}$, Mandyhra S. ${ }^{2}$, Mushtuk I. ${ }^{3}$, Ayshpur $0 .{ }^{4}$, Sytiuk M. ${ }^{5}$

Institute of veterinary medicine of NAAS, Donetska Str., 30, Kyiv, 03151, Ukraine; e-mail: 1ivm_naan@ukr.net,_2mandygra@ukr.net, ${ }^{3}$ mushtuk0104@gmail.com, ${ }^{4}$ olenaayshpur@gmail.com, ${ }^{5}$ snp1978@ukr.net

The purpose. To study epizootic situation concerning classical swine fever (CSF) in the world in 20122017 and to determine major factors which can promote spread of infection to Ukraine. Methods. Data of official veterinary statistics, materials of scientific publications and Internet-resource WOAH (http://www.oie.int) are used. Reports from 243 countries of the world including Europe (55), Asia (46), Africa (59), America (52) and Oceania (31) are analyzed. Results. It is established that for the last 6 years CSF flashes were registered in 30 countries $(12,3 \%)$ of 243 analyzed; in 92 countries $(37,9 \%)$ there were no revealed flashes of disease for the accounting period; 57 countries $(23,5 \%)$ did not give information on CSF; and in 64 countries $(26,3 \%)$ CSF had never registered. The greatest amount of CSF flashes was registered in countries of Asia (15), Central and South America (8), a little bit less in East Europe (3) and Africa. According to WOAH countries of Northern America, Europe (22), Australia, New Zealand, New Caledonia and Japan are officially recognized as CSF free. In Ukraine epizootic CSF was liquidated in 1997, however sporadic events of disease among wild boars still occur. Major factors which can lead to spread of CSF to our country include: migration of wild boars and their contact to house pigs, international trade, and also vaccination against CSF. Key tool of monitoring and prevention of emersion of new CSF flashes is duly and effective diagnostics. Conclusions. During 2012-2017 CSF flashes were registered in 30 countries, in particular in territory of Asia, Central and South America, and also East Europe and Africa. Northern America, the most part of Europe (22), Australia, New Zealand, New Caledonia and Japan are officially recognized as CSF free. Epizootic situation on CSF in Ukraine is concerning stable. For the last 6 years only one CSF flash had been registered among wild boars. However there is a high risk of repetitive occurrence of the disease.

Key words: classical swine fever, CSF, pigs, epizootic situation.

https://doi.org/10.31073/agrovisnyk201811-15

Introduction. Classical swine fever is a highly contagious generalized infectious disease of pigs. The causative agent of CSF is RNA-containing Classical swine fever virus (CSFV) of the genus Pestivirus within the Flaviviridae family $[1,2,3]$.

CSF is one of the most dangerous infectious animal diseases due to the economic and epidemiological impacts. The economic losses caused by the CSF outbreaks are extremely high and consists of high morbidity (up to $100 \%$ ) and mortality (up to $80-100 \%$ ) rates among domestic pigs and wild boars, stampingout strategy, control measures, trade restrictions [4, 5]. Due to all that CSF is considered to be the transboundary disease and must be reported to the World Organization for Animal Health (OIE) $[6,7]$.

The first case of CSF was reported in 1833 in North America (Ohio, USA), from where it was introduced into England in 1862 and quickly spread throughout Europe and Asia. At the end of the 19 century this disease was registered almost in all continents of the world [4, 7].

Although the fact that the CSF pandemic was overcome in the world, the registration of sporadic diseases outbreaks on all continents and the existence of CSF endemic areas (Central and South America, Eastern Europe and Asia) [8, 9], together with the intensification of international trades, demonstrate the existence of a permanent risk of infection redistribution.

The purpose - to study the epidemiological situation of CSF in the world in 2012-2017 and to identify the main factors that could lead to its spread in Ukraine as well as the tools for their prevention.

Materials and methods. Data of the CSF outbreaks in Ukraine and in the world during 2012-2017 were obtained from official veterinary statistics, materials of scientific publications and data of OIE website 
(http://www.oie.int). In general, annual reports of 243 countries, including Europe -55 countries, Asia - 46, Africa - 59, America -52 and Oceania - 31 were analysed.

Results. According to the obtained results of the OIE report analysis, it was established that over the past 6 years (2012-2017) CSF outbreaks have never been registered in 64 countries worldwide that is $26.3 \%$ of the 243 analysed countries; in 92 countries (37.9\%) there were no outbreaks of the disease during the analysed period; in 30 countries (12,3\%) CSF outbreaks have been recorded; 57 countries $(23.5 \%)$ did not provide information on CSF (Fig. 1).

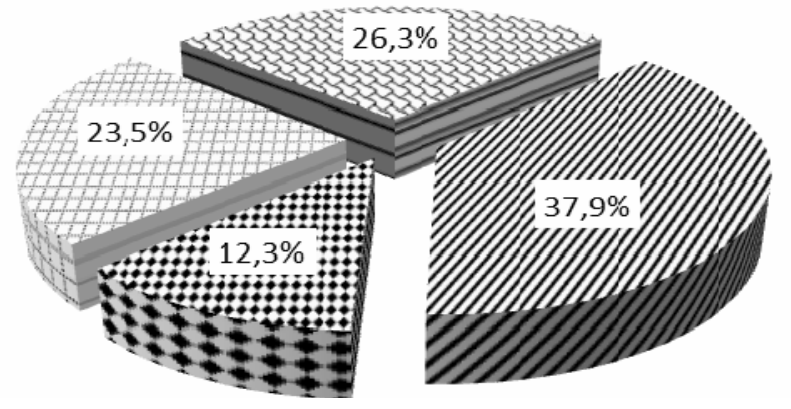

$$
\begin{aligned}
& \& \text { Therev is no information available on CSF } \\
& \text { N Never reported } \\
& : \text { There were nooutbreaks ofCSF during the analysed period } \\
& : \text { outbreaks have been recorded }
\end{aligned}
$$

Fig.1. Epidemiological situation of CSF in the world (2012-2017)

The epidemic situation of CSF has been researched in terms of continents. According to Figure 2, during 2012-2017 the most examined and satisfactory CSF epidemiological situation was in European countries.

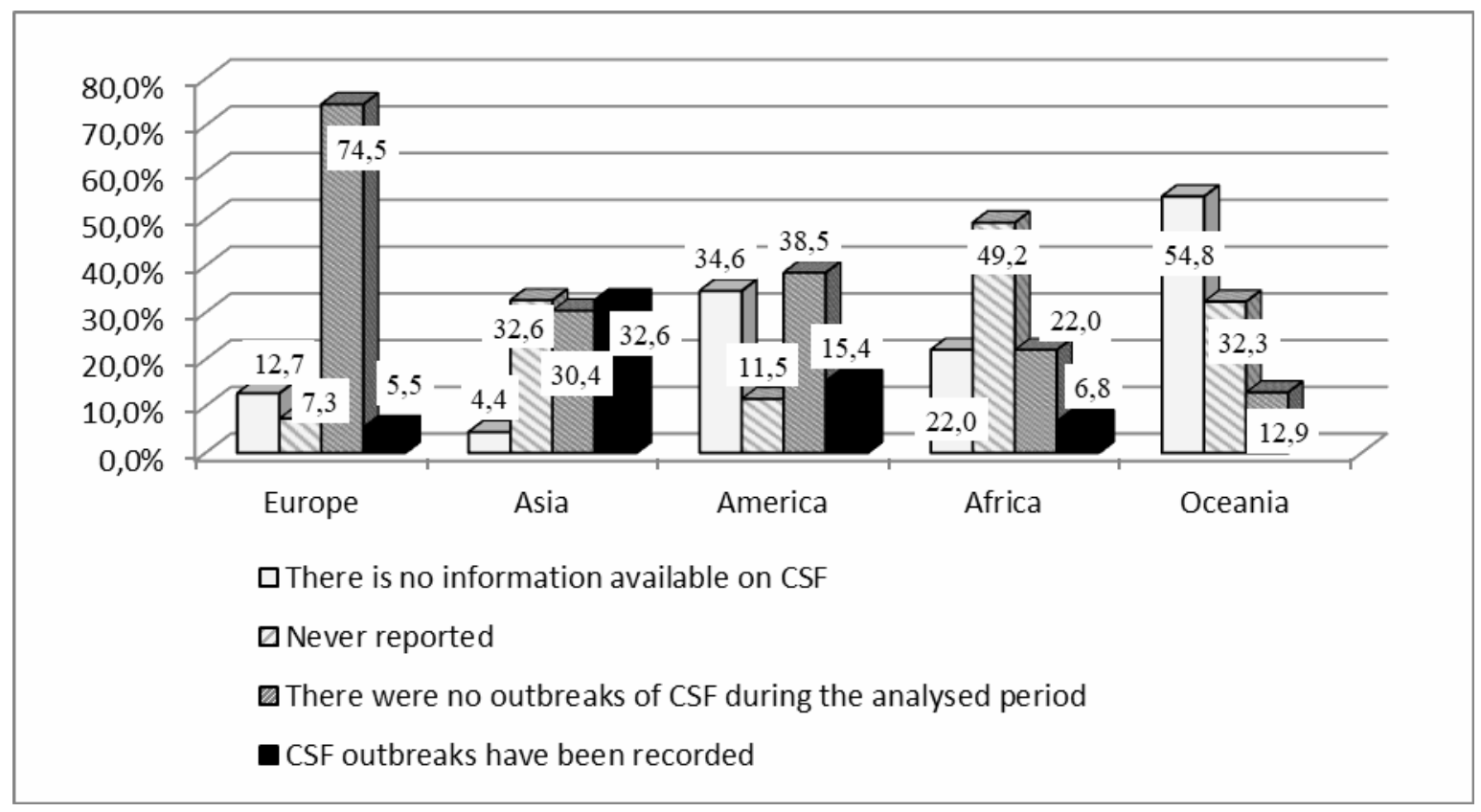

Fig.2. Epidemiological situation of CSF in the world in terms of continents (2012-2017)

In particular, from 55 European countries only in 3 countries $(5.5 \%)$ were outbreaks of CSF: in Latvia 145 outbreaks during 2012-2015; in Russia - 24 during 2012-2016; in Ukraine - 1 in 2015 (Table 1). At the

\begin{tabular}{|c|c|c|c|c|c|c|c|c|c|}
\hline \multicolumn{2}{|c|}{$\begin{array}{l}\text { Continent } \\
\text { № } n / \pi\end{array}$} & Country & 2012 & 2013 & 2014 & 2015 & 2016 & 2017 & Total \\
\hline \multirow{3}{*}{$\begin{array}{l}\text { ֻ } \\
\text { 일 } \\
\text { Шे }\end{array}$} & 1. & Latvia & 20 & 92 & 28 & 5 & - & - & 145 \\
\hline & 2. & Russia & 10 & 3 & 4 & 3 & 4 & - & 24 \\
\hline & 3. & Ukraine & - & - & - & 1 & - & - & 1 \\
\hline \multirow{2}{*}{$\frac{\pi}{\frac{\pi}{20}}$} & 1. & Butane & 1 & 5 & 1 & 1 & 2 & - & 10 \\
\hline & 2. & Vietnam & 128 & 80 & 65 & 44 & 44 & 50 & 411 \\
\hline
\end{tabular}
same time there were no outbreaks of CSF in 41 countries $(74.5 \%)$.

Table 1

Number of CSF outbreaks in the world in 2012-2017 


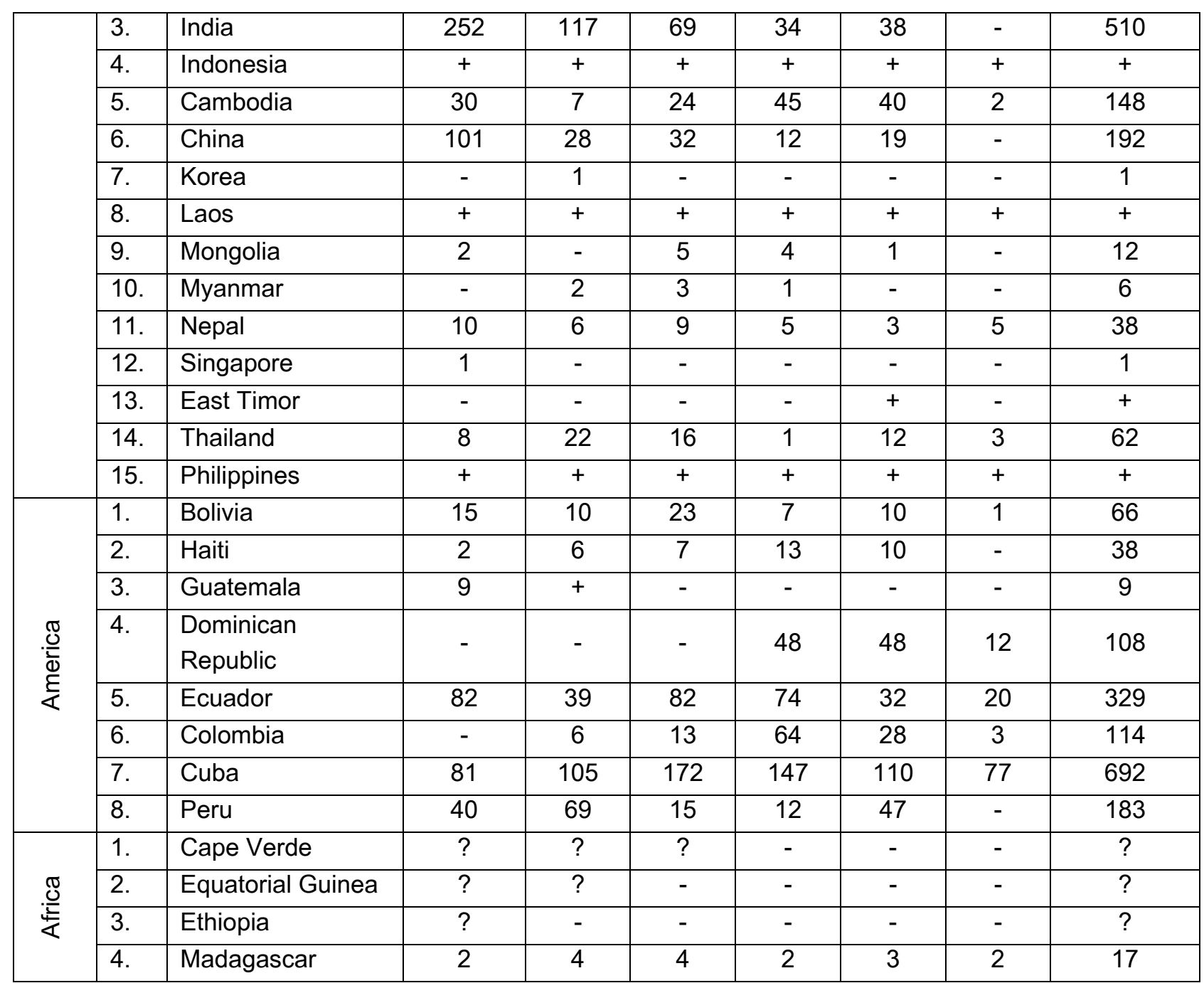

Notes: +- no detailed information of the outbreaks number in the report

$?-$ suspicion of diseases

However, the official status of the country free from CSF was only given to 22 countries of Europe: Austria (the last case of CSF in domestic swine - 1997, wild boars - 2000), Belgium (domestic swine 1997, wild boars - 2002), Great Britain (domestic swine - 2000), Denmark (domestic swine and wild boars 1933), Ireland (domestic swine - 1958), Italy (domestic swine - 2003), the Netherlands (domestic swine 1998), Liechtenstein, Luxembourg (domestic pigs swine - 2003), Germany (domestic swine - 2006; wild boars - 2009), Norway (domestic swine - 1963), Poland (domestic swine - 1994), Portugal (domestic swine and wild boars - 1985), Romania (domestic swine and wild boars - 2008), Slovakia (domestic swine and wild boars - 2008), Slovenia (domestic swine - 1996), Hungary (domestic swine - 1993), Finland (domestic swine - 1917), France (domestic swine - 2002, wild boars - 2007), Czech Republic (domestic swine - 1997, wild boars - 1999), Switzerland (domestic swine - 1993, wild boars - 1999) and Sweden (domestic swine 1944) (Fig. 3). 


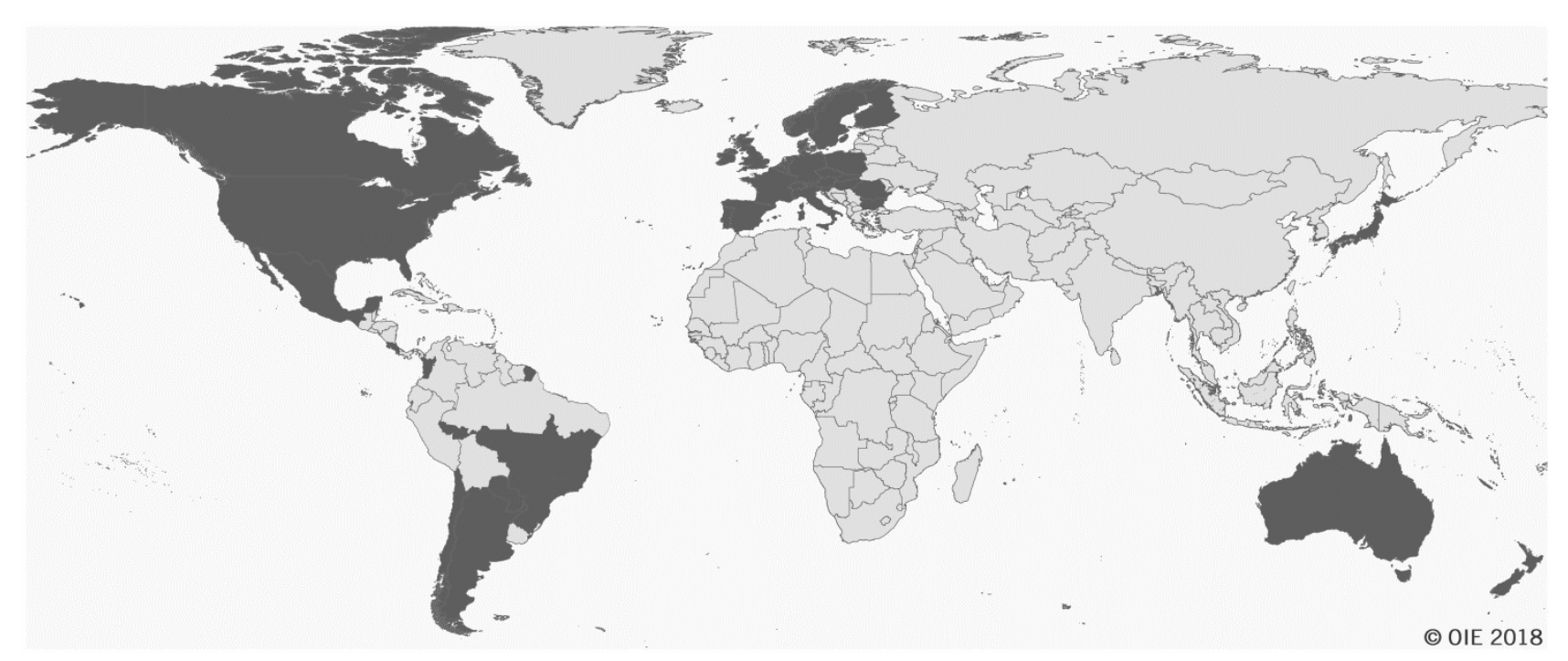

Fig. 3. OIE official status for CSF of the countries (2018): the countries and zones officially recognized as free from CSF are highlighted in dark; countries without an OIE official status for CSF - light [10].

Among the analyzed 52 countries of America in 20 countries (38.5\%) CSF outbreaks were not recorded during 2012-2017 (Fig. 2), 6 countries of them were officially recognized as free from CSF. These include the United States of America (the last case of CSF in domestic swine was in 1976) and Canada (domestic swine -1963), that represent the whole territory of North America, Mexico (domestic swine - 2009), Uruguay (domestic swine and wild boars - 1991) and Chile (domestic swine - 1996) in South America (Fig. 3).

On the most territory of Andes and Amazon CSF is still an endemic disease (Tab. 1). Positive changes have been achieved in Brazil (the last CSF outbreak in domestic swine was in 2003), that has a zone free from CSF. Caribbean countries (the Dominican Republic, Haiti and Cuba) continue to be endemic for CSF.

The most countries where CSF outbreaks are regularly recorded are located in Asia - 15 countries of the 46 analysed $(32.6 \%)$. In particular, China with almost half of the world's swine population and the countries of South Asia are an endemic for CSF, (Tab. 1). Only Japan is officially free for CSF (the last CSF outbreak in domestic swine was registered in 1992) (Fig. 3).

On the African continent, except South Africa and Madagascar, the epidemiological situation of CSF continues to be undefined. This is mainly due to the lack of implemented CSF surveillance, lack of reports in most of Africa, etc.

Among the island countries of Oceania, Australia was officially recognized as CSF free (the last outbreak of CSF in domestic swine and wild boars was in 1962), New Zealand (domestic swine and wild boars 1953) and New Caledonia. During 2012-2017 there were no outbreaks of CSF in Oceania.

Analysis of the world epidemic situation of CSF suggests that despite the successful elimination of CSF in several countries, currently the disease continues to be recorded almost on all continents.

In Ukraine, the epidemic of CSF was eradicated in 1997, however sporadic cases of the disease continue to be recorded from time to time $[7,11]$. In particular, two CSF outbreaks in wild boars were registered in Kyiv (Mironovsky district) and Cherkasy (Kaniv district) regions in 2001. During 2012-2017 only one CSF case has been registered in Ukraine. In particular, CSF was detected in 3 out of 5 wild boars, shot dead on December 21, 2014 in Borodyanka district, Kyiv region.

Despite the relative stability of CSF epidemiological situation, there is a risk of reoccurrence of CSF epidemic in Ukraine $[4,11]$. This dictate the need for investigation of the main factors that could lead to CSFV spread in Ukraine and development of the tools for their prevention.

One of the potential factors of CSFV spreading in Ukraine is the wild boars migration and their contact with domestic pigs. Wild boars are a natural reservoir and a source of CSFV infection that can support the circulation of the virus without any clinical signs. Migrating they can spread the CSFV over significant distances, including territories of bordering countries. In particular, there is a high risk of the CSFV introduction to the territory of Ukraine from Russia, where the CSF outbreaks are registered annually among wild boars (Tab. 1). 
In addition, there is a risk of CSF spreading as a transboundary disease due to intensification of world trades.

Another controversial factor is the vaccination of swine against CSF. Although the live vaccine's usage contributed to overcoming the CSF epidemic in our country, however, we should not forget about the possible negative consequences. In particular, mass vaccination of pigs against CSF usually leads to decreasing of the pathogen virulence. As a result the pathogenic microorganism can be maintained in the vaccinated population without any clinical symptoms and, under certain conditions, may cause an aggravation of the epidemiological situation [12]. Besides, the European experience of CSF eradication shows that live vaccines are able to protect pigs from disease and death, but not from infection. Thus, according to Moening Volker [13], the elimination of a field virus is impossible under conditions of mass vaccination against CSF, since the pathogen is hidden behind the "protective layer" of the general vaccination. That is why the countries where the preventive vaccination of pigs against CSF is used, especially by live vaccines, cannot be considered as CSF free.

In the past, most CSF control measures in pig farming were provided mainly due to total vaccination. Currently the situation has changed dramatically, most countries have refused to vaccinate.

Since Ukraine is focused on joining the European Union, the most probably, in the near future our country will have to refuse to carry out vaccination against CSF. In this case, the basis of the country's CSF free status will be strict maintenance of control measures, early detection of the pathogen sources and their subsequent elimination. At the same time, early and effective diagnosis of the disease will become a key tool for the surveillance and prevention of new CSF outbreaks emergence.

\section{Conclusions}

In 2012-2017, CSF outbreaks were registered in 30 countries worldwide, that is $12.3 \%$ of the 243 analysed countries. In particularly, those are countries of Asia (15 countries), Central and South America (8), less of Eastern Europe (3) and Africa. The North American, most part of Europe (22 countries), Australia are officially free from CSF.

In Ukraine, the current situation of CSF is relatively stable, over the past 6 years, only one outbreak has been reported in wild boars, but there is still a risk of CSF virus introduction into the country and its spreading.

\section{References}

1. Макаров В.В., Грубый В.А., Груздев Л.Н., Сухарев О.И. (2012). Список МЭБ и трансграничне инфекции животных: монография. Владимир: ФГБУ «ВНИИЗЖ», 162 р. [In Russian].

2. Gregg D. (2002). Update on classical swine fever (hog cholera). J. of Swine Health and Production. V. 10 (1). P. $33-37$.

3. Moennig V., Floegel-Niesmann G., Greiser-Wilke I. (2003). Clinical signs and epidemiology of classical swine fever: a review of new knowledge. Veterinary J. V. 165. P. $11-20$.

4. Klestova Z.S. (2016). Emerdzhentni virusni zakhvoriuvannia tvaryn ta prohnozuvannia bioryzykiv. [Emergency viral animal diseases and prediction of biorhyzics]. Veterynarna biotekhnolohiia. Vyp. 29. P. 117 - 131. [In Ukrainian].

5. Penrith M.L., Vosloo W., Mather C. (2011). Classical Swine Fever (Hog Cholera): Review of Aspects Relevant to Control. Transboundary and Emerging Diseases. V. 58. P. 187 - 196.

6. Chapter 2.8.3. (2008). Classical swine fever (hog cholera). OIE Terrestrial Manual. P. $1092-1106$.

7. Korniienko L.le. (2015). Klasychna chuma svynei: istorychni aspekty, suchasna epizootychna sytuatsiia v sviti ta Ukraini, imunitet i vaktsynoprofilaktyka. [Classical swine fever: historical aspects, current epizootic situation in the world and Ukraine, immunity and vaccine prophylaxis]. Naukovyi visnyk veterynarnoi medytsyny. No 2. P. 5 - 13. [In Ukrainian].

8. Edwards S., Fukusho A., Lefevre P.C. et al. (2000). Classical swine fever: The global situation. Veterinary Microbiology. V. 73. P. $103-119$.

9. Postel A., Moennig V., Becher P. (2013). Classical swine fever in Europe - the current situation. Berliner und Münchener tierärztliche Wochenschrift. V. 126 (11 - 12). P. 468 - 475. 
10. Map of CSF official status. OIE World Organisation for Animal Health Website. 2017. URL http://www.oie.int/animal-health-in-the-world/official-disease-status/classical-swine-fever/mapof-csf-officialstatus.

11. Mushtuk I.Iu. (2014). Klasychna chuma svynei sered populiatsii dykykh i sviiskykh tvaryn. [Classical swine fever among wild and domestic animals]. Veterynarna biotekhnolohiia. Vyp. 24. P. 115 - 119. [In Ukrainian].

12. Sytiuk M.P., Mushtuk I.lu., Nychyk S.A., Obrazhei A.F. (2012). Obgruntuvannia vidminy vaktsynatsii proty klasychnoi chumy svynei yak holovnoho chynnyka pry vprovadzhenni zakhodiv po eradykatsii. [Justification for the abolition of vaccination against classical swine fever as a major factor in the implementation of eradication measures]. Veterynarna biotekhnolohiia. Vyp. 21. P. 177 - 186. [In Ukrainian].

13. Moennig V. (2000). Introduction to classical swine fever: virus, disease and control. Veterinary Microbiology. V. 73, Is. 2 - 3. P. $93-102$.

14. Mandyhra S.S., Muzykina L.M., Ishchenko L.M. et al. (2017). Rozrobka test-systemy dlia dyferentsiinoi diahnostyky afrykanskoi ta klasychnoi chumy svynei metodom ZT-PLR u rezhymi realnoho chasu. [Development of a test system for differential diagnosis of African and classical swine fever by RTPCR in real-time mode]. Veterynarna biotekhnolohiia. Vyp. 31. P. 103 - 111. [In Ukrainian]. 